\title{
Author Correction: Changes in gene expression predictably shift and switch genetic interactions
}

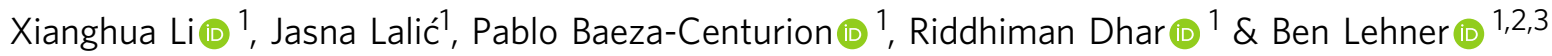

Correction to: Nature Communications https://doi.org/10.1038/s41467-019-11735-3, published online 29 August 2019.

The original version of this Article contained an error in the spelling of the author Jasna Lalić, which was incorrectly given as Jasna Lalic. This has now been corrected in both the PDF and HTML versions of the Article.

Published online: 17 September 2019

\begin{abstract}
(c) (i) Open Access This article is licensed under a Creative Commons Attribution 4.0 International License, which permits use, sharing, adaptation, distribution and reproduction in any medium or format, as long as you give appropriate credit to the original author(s) and the source, provide a link to the Creative Commons license, and indicate if changes were made. The images or other third party material in this article are included in the article's Creative Commons license, unless indicated otherwise in a credit line to the material. If material is not included in the article's Creative Commons license and your intended use is not permitted by statutory regulation or exceeds the permitted use, you will need to obtain permission directly from the copyright holder. To view a copy of this license, visit http://creativecommons.org/licenses/by/4.0/.
\end{abstract}

(C) The Author(s) 2019

\footnotetext{
${ }^{1}$ Centre for Genomic Regulation (CRG), The Barcelona Institute of Science and Technology, Dr. Aiguader 88, Barcelona 08003, Spain. ${ }^{2}$ Universitat Pompeu Fabra (UPF), Barcelona, Spain. ${ }^{3}$ ICREA, Pg. Luis Companys 23, Barcelona 08010, Spain. Correspondence and requests for materials should be addressed to B.L. (email: ben.lehner@crg.eu)
} 